\title{
Influence of Different Parameters on the Smile Esthetic Perception of Dentists, Prosthodontists and Laypeople
}

\author{
Genel Diş Hekimleri, Protetik Diş Tedavisi Uzmanları ve Meslek \\ Dışı Bireylerin Gülümseme Estetiği Algılarının Değerlendirilmesi \\ (D) Merve Köseoğlu ${ }^{1}$, (1) Funda Bayındır²
}

\author{
${ }^{1}$ Sakarya University Faculty of Dentistry, Department of Prosthodontics, Sakarya, Turkey \\ ${ }^{2}$ Atatürk University Faculty of Dentistry, Department of Prosthodontics, Erzurum, Turkey
}

Keywords

Esthetics, dental, diastema

Anahtar Kelimeler

Estetik, dental, diastema

Received/Geliş Tarihi : 24.09 .2020

Accepted/Kabul Tarihi : 23.12.2020

doi:10.4274/meandros.galenos.2020.83723

Address for Correspondence/Yazışma Adresi: Merve Köseoğlu MD

Sakarya University Faculty of Dentistry, Department of Prosthodontics, Sakarya, Turkey

Phone : +902642954117

E-mail : mervekoseoglu@sakarya.edu.tr

ORCID ID: orcid.org/0000-0001-9110-9586

(c) Meandros Medical and Dental Journal, Published by Galenos Publishing House.

This is article distributed under the terms of the

Creative Commons Attribution NonCommercial 4.0

International Licence (CC BY-NC 4.0).

\begin{abstract}
Objective: This study aimed to determine different parameters on the smile aesthetic perceptions of prosthodontists, general practitioner dentists and laypeople.

Materials and Methods: A close-up, posed smile image of a young woman was digitally altered by using software. The shape of the incisal curvature was arranged as ideal, flat, reverse and the width-to-length ratio of the maxillary central tooth was set to $75 \%, 80 \%$ and $85 \%$ in the photographs. Incisal edge asymmetries in the maxillary central, lateral and canine teeth and midline diastema at varying dimensions of $0.5 \mathrm{~mm}, 1 \mathrm{~mm}$ and $2 \mathrm{~mm}$ were created. As the control group, a photograph without any asymmetry or diastema was used. A questionnaire was created using these photographs and subsequently administered by a researcher. The images were assessed by 180 evaluators, which included 60 prosthodontists, 60 dentists and 60 laypeople. Each evaluator was asked to rate the smile images with the help of a visual analogue scale. Obtained data were analysed by using One-Way ANOVA with post hoc Tukey test.

Results: The ideal incisal curvature, small amount of diastemas and incisal asymmetries and $80 \%$ width-to-length ratio of the maxillary central teeth were more aesthetic to all participants $(p<0.001)$.

Conclusion: Laypeople's aesthetic scores were higher than those of general practitioner dentists and prosthodontists in all groups. Aesthetic scores increase as the size of asymmetries decreases. Diastemas and incisal edge asymmetries were less perceptible laterally.
\end{abstract}

Öz

Amaç: Bu çalışmanın amacı protetik diş tedavisi uzmanları, genel diş hekimleri ve meslek dışı bireylerin gülümseme estetiği algılarını belirlemektir.

Gereç ve Yöntemler: Bu çalışmada, kadın bir gönüllüden poz gülümsemesi esnasında alınan yakın çekim fotoğrafları kullanıımıştır. Fotoğraflar bir yazılım programıyla dijital olarak düzenlenmiştir. Fotoğraflarda insizal kurvatür şekli ideal, düz ve ters olarak ve maksiller santral dişin genişliği $\% 75, \% 80$ ve $\% 85$ olarak değiştirilmiştir. Maksiller santral, lateral ve kanin dişlerinde $0,5 \mathrm{~mm}, 1 \mathrm{~mm}$ ve 2 $\mathrm{mm}$ olmak üzere farklı boyutlarda insizal asimetri ve orta hatta aynı boyutlarda diastema oluşturulmuştur. Kontrol grubu olarak ise, herhangi bir asimetriye veya diastemaya sahip olmayan bir fotoğraf kullanılmıştır. Bu fotoğraflar kullanılarak bir anket oluşturulmuş ve bir araştırmacı tarafından uygulanmıştır. Fotoğraflar 60 
genel diş hekimi, 60 protetik diş tedavisi uzmanı ve 60 meslek dışı birey olmak üzere toplam 180 kişi tarafından değerlendirilmiş̧ir. Her bir katılımcıdan fotoğrafları görsel analog skala yardımıyla değerlendirmesi istenmiştir. Elde edilen veriler tek yönlü varyans analizi ve post hoc Tukey testi ile değerlendirilmiştir.

Bulgular: İdeal insizal kurvatür, küçük boyutlardaki diastemalar ve insizal asimetriler ile \%80 genişlik/uzunluk oranına sahip maksiller santral dişler bütün katılımcılar tarafından daha estetik bulunmuşlardır $(p<0,001)$.

Sonuç: Tüm gruplarda meslek dışı bireylerin estetik skorları, genel diş hekimleri ve protetik diş tedavisi uzmanlarından yüksek bulunmuştur. Asimetri azaldıkça estetik skorlar artmıştır. Orta hattan lateral yönde gidildikçe, daha büyük boyutlardaki insizal kenar asimetrileri algılanmıştır.

\section{Introduction}

Esthetics, which becomes increasingly important in modern dentistry, means an interest in beauty or liking of beauty (1). The smile plays a fundamental role in facial esthetics and attractiveness (2). Furthermore, an attractive and pleasant smile creates the first positive effect in the social lives of individuals and ensures that the person is accepted in bilateral relationships (3). Smile esthetics, one of the most essential components of dentofacial esthetics, is of major importance in dental treatments nowadays $(4,5)$. In smile esthetics, factors such as gingival display $(6,7)$, ratio and symmetry of maxillary incisors (8-10), incisal curvature (11-14), the presence of gingival and dental asymmetries $(3,15-19)$, and the presence of midline diastema are effective $(15,20,21)$.

Esthetic perception may vary from person to person with the effect of social environment and personal experiments (22). Due to the same reason, there are differences among beauty perceptions of laypeople and dental professionals (23). A smile that is beautiful and attractive to dentists may not create the same perception in other individuals (24). When evaluating esthetics, dentists were determined to be stricter than laypeople (15).

There are many studies in the dental literature comparing the perceptions of smile esthetics of dentists, orthodontists, and laypeople $(3,9,15,18,25$ 36). However, there has been no extensive study in the dental literature examining the effects of the different smile esthetic parameters on prosthodontists' smile esthetic perception.

The aim of this study was to determine the effects of different smile esthetic parameters, such as incisal curvature shape, incisal asymmetry of anterior teeth, the presence of diastema, different width/ length ratios of central teeth on the smile esthetic perceptions of prosthodontists, general practitioner dentists and laypeople. The hypothesis of the study was that participants' occupations (general dentists, prosthodontists, laypeople) would not significantly affect their perceptions of smile esthetics.

\section{Materials and Methods}

This research obtained the research ethics committee approval from the Sakarya University Faculty of Medicine (protocol number: 71522473/050.01.04/537, date: 08.10.2020). Also, a female individual who posed for the study signed an image use authorization. All participants has signed an informed constent form (26).

Sample size in the study was determined by using a software (G*Power 3.01, Franz Faul, ChristianAlbrechts-Universität Kiel, Kiel, Germany) to achieve $80 \%$ power, and "effect size" was 0.25 . According to the results of this calculation, 56 subjects in each group were necessary. However, $\mathrm{n}=60$ was determined as safety margin. Consequently the present study was conducted with a total of 180 volunteers which was consistent with the other studies that used similar methods $(9,26,37)$.

In this study, three groups evaluated different smile images: Prosthodontists, dentists and, laypeople. The inclusion criteria for prosthodontists and dentists were completing their specializations or dental educations at least 2 years. This information was confirmed by the Turkish Society of Dentistry. For laypeople, inclusion criterias were being older than 18 years old, having a university education, not being a dental technician, oral hygienist and dental assistant, not having any dental education, not being associated with artistic activities or not being an artist. The present study was conducted among laypeople in a shopping mall (38). While, conducted among generaal practitioner dentists and prosthodontists in a congress center.

A close-up smile image of a young female volunteer having an attractive smile without any facial asymmetries (39) were taken by using a DSLR 
camera (Nikon, DX SWM VR ED IF Aspherical $\varnothing 72$, Thailand). Changes were made in photographs by using a software (Photoshop CS6 v.13.0.4; Adobe Inc, Mountain View, CA, USA) $(9,18,23-25,36-44)$.

By using the photoshop program a symmetrical smile (right to left) was created, most parts of chin, cheeks and, nose were removed discoloration in skin and, lips were retouched, to reduce variables within the images $(15,16)$. Photographs were arranged to achieve identical measurements of volunteer. It was provided that each millimeter measured on the digital image was equivalent to the volunteer, determining maxillary central teeth as a reference point (45). Furthermore, all of the images were standardized in 300 dots per inch resolution $(9,46)$.

In the photographs, the shape of the incisal curvature was changed to be ideal, flat, and reverse (Figure 1) $(7,11,18,25,32,37,47)$. Midline diastemas were also created at varying dimensions: $0.5 \mathrm{~mm}$, $1 \mathrm{~mm}, 1.5 \mathrm{~mm}$ and $2 \mathrm{~mm}$ (Figure 2) (17,25,33,34). Furthermore, $0.5 \mathrm{~mm}, 1 \mathrm{~mm}$, and $2 \mathrm{~mm}$ incisal edge asymmetries were created in maxillary central, lateral and canine teeth (Figure 3-5) $(3,16,25,34)$. The width to length ratio of the maxillary central tooth was changed to be $75 \%, 80 \%$, and $85 \%$ (Figure 6$)(48,49)$. A questionnaire was created by the changing esthetic

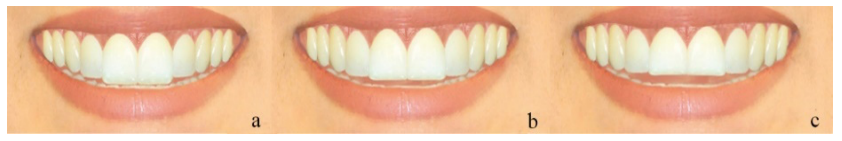

Figure 1. Alterations in smile arc a) ideal b) flat c) reverse

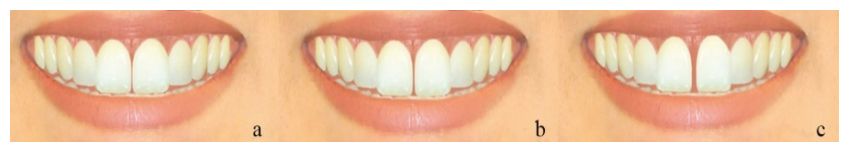

Figure 2. Different degrees of midline diastema a) $0.5 \mathrm{~mm}$ b) 1 $\mathrm{mm} \mathrm{c)} 2 \mathrm{~mm}$

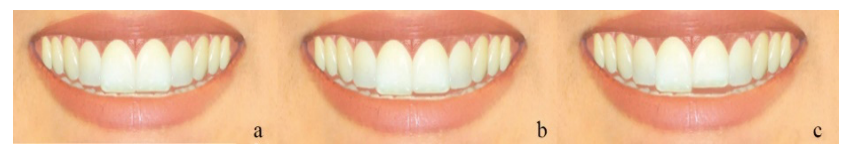

Figure 3. Different incisal asymmetries in maxillary central teeth a) $0.5 \mathrm{~mm} \mathrm{~b}) 1 \mathrm{~mm} \mathrm{c}) 2 \mathrm{~mm}$

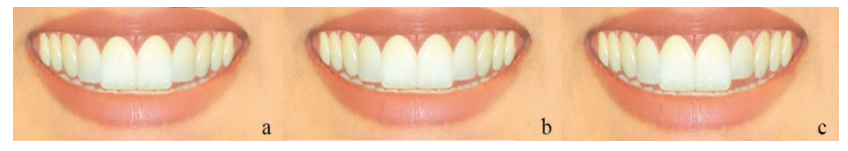

Figure 4. Different incisal asymmetries in maxillary lateral teeth a) $0.5 \mathrm{~mm} \mathrm{b)} 1 \mathrm{~mm}$ c) $2 \mathrm{~mm}$ parameters in the photographs and turning them into questions by a software (Google Docs, Google Inc., Mountain View, CA) (46).

Participants' sociodemographic datas including age, gender, occupation and education level were gathered by using a questionnaire (17). Images were arranged in a random order $(15,45)$ and showed to the participants individually by a single researcher. The observation time for each image was determined as 20 seconds (38). The participants were allowed to view one image at a certain time, and it was not allowed to go back to other photographs and compare the images (50).

The esthetic value of each image was determined using the visual analog scale (VAS) $(9,15,23,26,41$ 46). The VAS was prepared to be $10 \mathrm{~mm}$ long, and the participants were asked to score different smiles according to their own esthetic values. The esthetic score was arranged to be between 0-10. Zero corresponds to the minimum (least attractive), while ten corresponds to the maximum (most attractive) esthetic value (49).

\section{Statistical Analysis}

Statistical analysis was performed using the SPSS program (version 22.0, SPSS). Kolmogorov-Smirnov normality test was conducted to the assessment of the data for skewness, kurtosis, and outliers, it was concluded that the data was normally distributed. Then, One-Way ANOVA tests were performed within each group to assess how the study groups rated at each level of deviation and within each level of variation to compare each groups' esthetic scores. Multiple comparisons corrected with Bonferroni adjustments and post hoc Tukey test were performed to calculate the threshold level of deviation at which each study group was differentiated and also to determine how groups' esthetic scores have distinguished from the

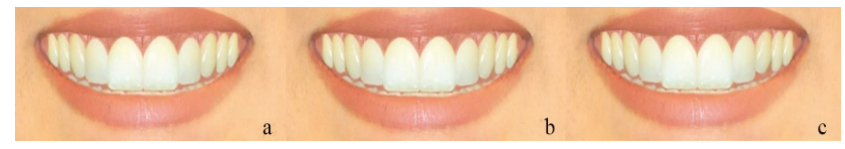

Figure 5. Different incisal asymmetries in maxillary canine teeth a) $0.5 \mathrm{~mm} \mathrm{b)} 1 \mathrm{~mm} \mathrm{c)} 2 \mathrm{~mm}$

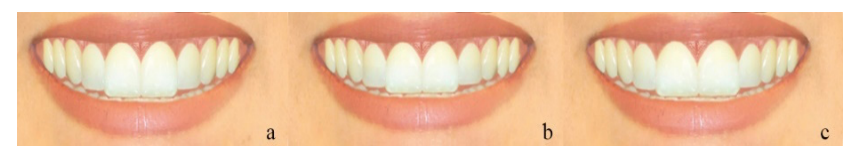

Figure 6. Different width to length ratio of maxillary central teeth a) $75 \%$ b) $80 \%$ c) $85 \%$ 
other groups. The level of significance was set at $\alpha=0.05$.

\section{Results}

The results of the study presented that, $47.2 \%$ of the participants were men while $52.8 \%$ were women, $27.8 \%$ were between $26-35$ years and $24.4 \%$ were between 36-45 years old. The participants' demographic characteristics are shown in Table 1.

The mean esthetic score of the smiles with the ideal incisal line was 8.4, flat incisal line was 5.1 and reverse incisal line was 3.3. The esthetic scores of smiles with ideal incisal line were higher than flat and reverse incisal lines $(p<0.001)$. In addition, esthetic scores of laypeople were higher than dentists and laypeople in each incisal line type but there wasn't any difference between groups ( $p>0.05)$ (Graphic 1 ).

As a result of the study, the highest esthetic scores were observed in $0.5 \mathrm{~mm}$ midline diastema (mean: 7.8); lowest esthetic scores in $2 \mathrm{~mm}$ midline diastema (mean: 4.4$)$ in all study groups $(p<0.001)$. Dentists' and prosthodontists' esthetic scores were lower than laypeople's in each level of diastema $(p<0.001)$. Threshold levels of significant difference of esthetic scores were $0.5 \mathrm{~mm}$ for prosthodontists, 1 $\mathrm{mm}$ for dentists, $2 \mathrm{~mm}$ for laypeople. Prosthodontists were more critical than general practitioner dentists and laypeople when evaluating midline diastemas (Graphic 2).

When the incisal edge asymmetries of maxillary anterior teeth were compared, the highest esthetic scores were observed in canine teeth with $0.5 \mathrm{~mm}$ incisal asymmetry (mean: 7.2); the lowest esthetic scores were observed in the central teeth with $2 \mathrm{~mm}$ incisal asymmetry (mean 3.4). When the amount of incisal asymmetries increased, the esthetic scores of maxillary central, lateral, and canine teeth decreased $(p<0.001)$. Laypeople had higher esthetic scores than

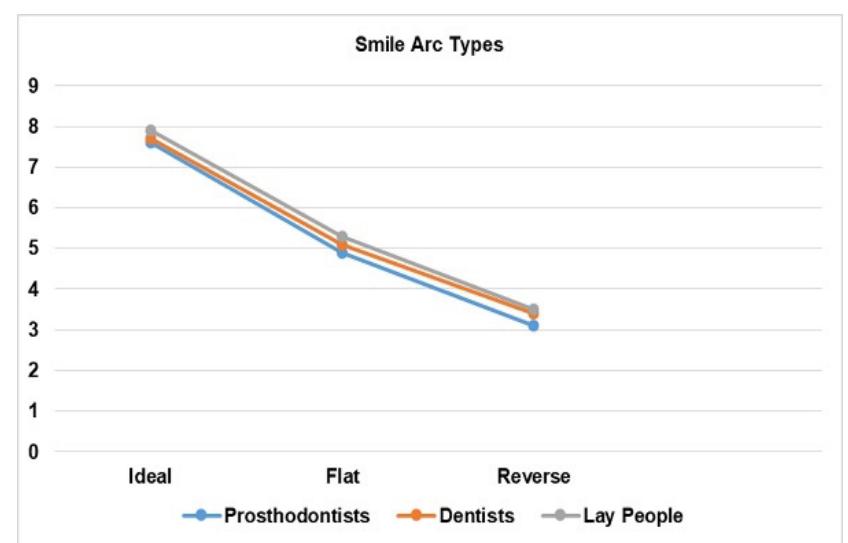

Graphic 1. Attractiveness of images with different smile arc types

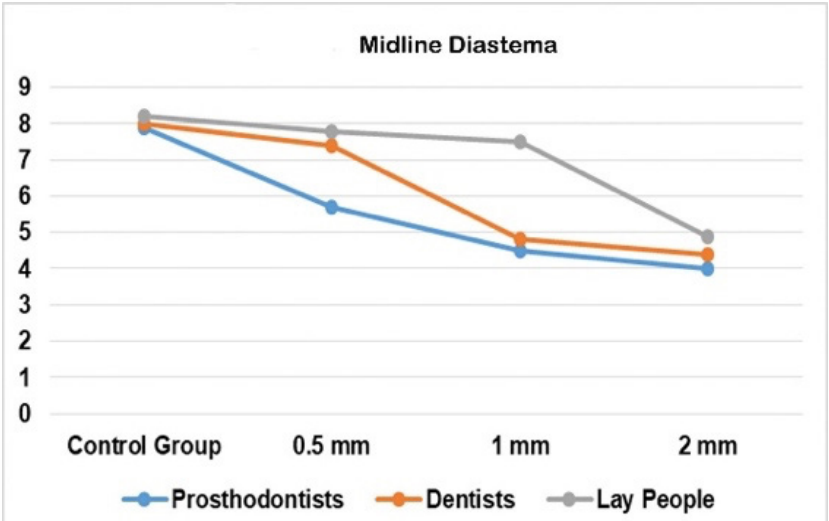

Graphic 2. Attractiveness of images with different degrees of midline diastema

\begin{tabular}{|c|c|c|c|}
\hline Characteristics & Prosthodontists & Dentists & Laypeople \\
\hline \multicolumn{4}{|l|}{ Genders } \\
\hline Male & $31(51.7 \%)$ & $26(43.3 \%)$ & $28(46.7 \%)$ \\
\hline Female & $29(48.3 \%)$ & $34(56.7 \%)$ & 32 (53.3\%) \\
\hline \multicolumn{4}{|l|}{ Age groups } \\
\hline $18-25 y$ & $0(0 \%)$ & $3(5 \%)$ & $16(26.7 \%)$ \\
\hline $26-35 y$ & $20(33.3 \%)$ & $17(28.3 \%)$ & $13(21.7 \%)$ \\
\hline $36-45 y$ & 19 (31.7\%) & $14(23.3 \%)$ & $11(18.3 \%)$ \\
\hline $46-55 y$ & $11(18.3 \%)$ & $14(23.3 \%)$ & 9 (15\%) \\
\hline $55-65 y$ & $7(11.7 \%)$ & $8(13.3 \%)$ & $6(8.3 \%)$ \\
\hline$>65 y$ & $3(5 \%)$ & $3(6.8 \%)$ & $6(10 \%)$ \\
\hline
\end{tabular}


dentists and laypeople in each level of asymmetries of all teeth $(p<0.001)$. Prosthodontists were more critical than general practitioner dentists and laypeople when evaluating incisal edge asymmetries. Threshold levels of significant difference of esthetic scores were 0.5 $\mathrm{mm}$ for prosthodontists, $1 \mathrm{~mm}$ for dentists, $2 \mathrm{~mm}$ for laypeople in all teeth. Canine teeth's esthetic scores in each level of incisal asymmetries were higher than central and lateral incisors, in all groups $(p<0.001)$ (Graphic 3-5).

Maxillary central teeth with $80 \%$ width/length ratio had highest esthetic scores (mean 7.9), while the 85\% ratio had lowest esthetic scores (mean: 5.9). Esthetic scores of prosthodontists and dentists were lower than laypeople in $75 \%$ width/length ratio $(p=0.011)$, in $80 \%$ ratio $(p=0.007)$, in $\% 85$ ratio $(p=0.002)$ (Graphic 6$)$.

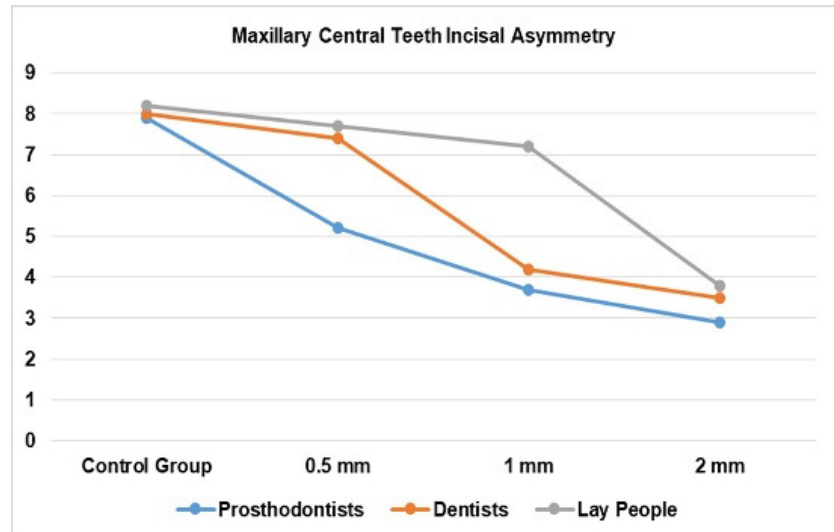

Graphic 3. Attractiveness of images with different incisal asymmetries of central teeth

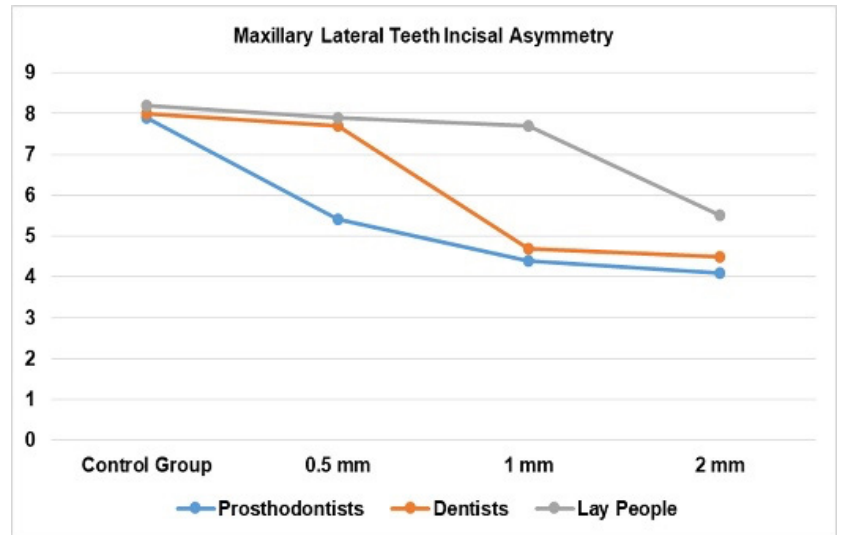

Graphic 4. Attractiveness of images with different incisal asymmetries of lateral teeth

\section{Discussion}

Dental and gingival asymmetries adversely affect esthetics in adults (9). Age, genders, professions, ethnicities may influence people's smile esthetic perceptions (28-31). As a consequence of the present study, while the esthetic scores of smiles which had different incisal curvature shapes, the esthetic scores of smiles had different amounts of asymmetry, rotation, and diastema in the anterior teeth and different width to length ratios of the central tooth, differed among dentists, prosthodontists and laypeople. The null hypothesis, which estimated that there would be no differences among the study groups, was partially accepted.

When the incisal edge curvatures of the upper anterior teeth is parallel to the lower lip curvature, this is defined as the ideal smile arc (11). While the ideal smile arc increases the attractiveness of the

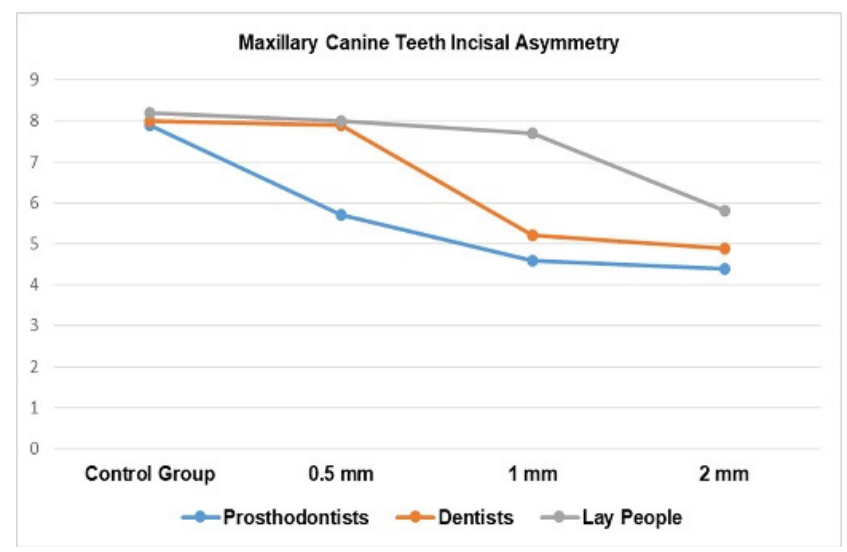

Graphic 5. Attractiveness of images with different incisal asymmetries of canine teeth

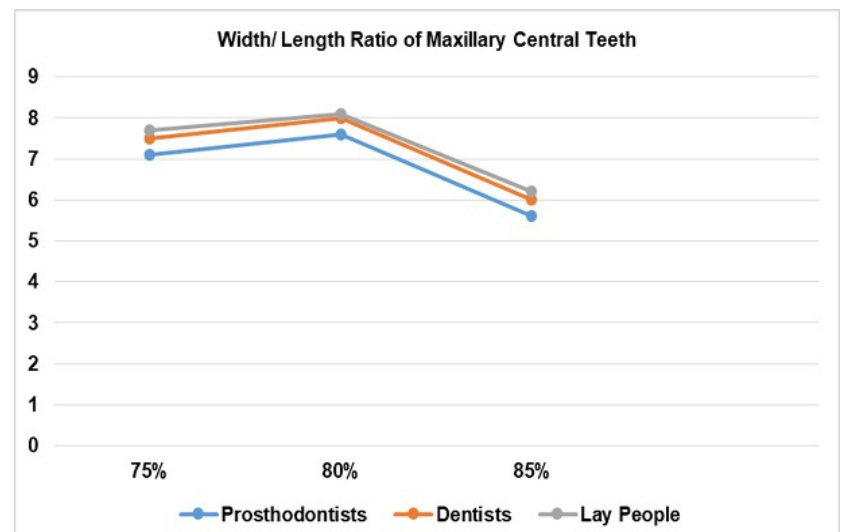

Graphic 6. Attractiveness of images with maxillary central teeth's different width/length ratios 
smile, the straight smile arc decreases it $(11,32,45)$. In different ethnicities, different smile arcs can be considered esthetic (31). In the literature, it was reported that orthodontists, dentists, and laypeople found the ideal smile arc more esthetic, while they found the flat smile arc less esthetic $(7,25,45)$. Rodrigues et al. (20) stated that laypeople found the reverse smile arc less esthetic. In our study, similarly to studies in the literature $(7,11,25,32,45)$, while the ideal smile arc was perceived to be more esthetic by prosthodontists, dentists, and laypeople, flat smile arc obtained lower esthetic scores. Furthermore, in our study, similarly, Rodrigues et al. (20) reverse smile arc received the lowest esthetic scores in all groups.

In the literature, some researchers $(15,25)$ noted that the esthetic scores of those with small diastemas $(0.5 \mathrm{~mm})$ in the midline were generally higher than those with $1 \mathrm{~mm}, 1.5 \mathrm{~mm}$ and $2 \mathrm{~mm}$ diastemas. Kokich et al. (15) stated that in order not to find the smile attractive, the threshold value of the diastema in the midline was 1 and $1.5 \mathrm{~mm}$ for orthodontists, and 2 $\mathrm{mm}$ for dentists and laypeople. At the same time, Al Taki et al. (25) concluded that the threshold value of midline diastema was $1 \mathrm{~mm}$ for orthodontists and dentists and $1.5 \mathrm{~mm}$ for laypeople. While in India, for accepting that the diastema is esthetic, the threshold value is $1.5 \mathrm{~mm}$ for orthodontists, general dentists, and laypeople (34), in Africa, this value is $2-3 \mathrm{~mm}$ for laypeople (33). According the results of this study, different from other studies $(15,25,33)$ threshold values were $0.5 \mathrm{~mm}$ for prosthodontists, $1 \mathrm{~mm}$ for dentists, $2 \mathrm{~mm}$ for laypeople. In our opinion, this difference is because of the fact that prosthodontists are stricter than orthodontists in detecting midline diastemas.

In the dental literature, Kokich et al. (3) evaluated asymmetries in the length of teeth, and they reported that orthodontists could distinguish even a $0.5 \mathrm{~mm}$ shortness of the crown length of teeth, dentists could notice a $1.5 \mathrm{~mm}$ shortness of the crown length, and laypeople could notice a $2 \mathrm{~mm}$ shortness of the crown length. It was reported that laypeople living in the United States did not accept teeth with a 1.5-2 mm shortness as symmetric (16), while those in India did not accept teeth with a shortness of more than 1.5 $\mathrm{mm}$ (34), and the Arabic people did not accept a 2 $\mathrm{mm}$ shortness as symmetric (25). As a result of the current study, similarly to the study by Kokich et al. (3) only the esthetic scores of prosthodontists decreased in the case of a $0.5 \mathrm{~mm}$ shortness in lateral and central incisiors and canine teeth. Similarly to other studies in the literature $(16,25)$, the esthetic scores of general dental practitioners decreased in the case of a $1 \mathrm{~mm}$ shortness, while the esthetic scores of laypeople decreased in the case of a $2 \mathrm{~mm}$ shortness.

Furthermore, Chiche and Pinault (14) considered that symmetry at the midline was essential, while more laterally a certain amount of asymmetry was permissible. According to the results of this study, supporting Chiche and Pinault (14) incisal asymmetries of central teeth had the lowest while canine teeth had the highest esthetic scores, and also esthetic scores increased laterally.

The ideal width to length ratio of maxillary central incisors is between $75-85 \%$ (37). Sterrett et al. (48) stated that the teeth size of males was larger than that of females, and while the width/length ratio was expected to be closer to $75 \%$ for females, values close to $85 \%$ were more acceptable for males. Álvarez Álvarez et al. (27) reported that maxillary central teeth with a width/length ratio of $85 \%$ were considered to be more esthetic by dentists and laypeople. Unlike the study by Álvarez - Álvarez et al. (27) as a results of the current study, the esthetic scores of maxillary central teeth, which had a width/length ratio of $80 \%$, were higher in all three groups. This situation is thought to be related to the changes in esthetic perception due to the difference in ethnicity in the two studies.

In our opinion, information obtained about the perceptions of smile esthetics of prosthodontists, dentists and laypeople as a result of the current study will help clinicians in treatments in the esthetic zone. Knowing which situations are found as esthetic or unesthetic by patients can help dental professionals to avoid unnecessary treatments, especially in the esthetic zone. The first limitation of the current study is that not all parameters of the esthetic checklist were evaluated. The another limitation was that 2D photographs of volunteer were evaluated and 3D models were not used. The third limitation is that individuals were not asked to evaluate the photographs repetitively over a specific period of time, and the results were obtained with the evaluation performed by the individuals once. The fourth limitation is that this study was performed only in one ethnicity, and the results of the study did not 
provide general information about the smile esthetics of prosthodontists, dentists, and non-professionals around the world.

\section{Conclusion}

Within the limitations of the present study, it was concluded that:

1. Ideal smile arc had the highest esthetic scores.

2. Prosthodontists can notice smaller diastemas and asymmetries in comparison with dentists and laypeople.

3. As the size of asymmetries and diastemas increases, esthetic scores decrease at that rate.

4. The maxillary central tooth with a width/length ratio of $80 \%$ has the highest esthetic scores.

Ethics

Ethics Committee Approval: This research obtained the research ethics committee approval from the Sakarya University Faculty of Medicine (protocol number: 71522473/050.01.04/537, date: 08.10.2020).

Informed Consent: All participants has signed an informed constent form.

Peer-review: Externally peer-reviewed.

\section{Authorship Contributions}

Concept: M.K., Design: M.K., Supervision: F.B., Fundings: M.K., Materials: M.K., Data Collection or Processing: M.K., Analysis or Interpretation: M.K., Literature Search: M.K., Critical Review: F.B., Writing: M.K.

Conflict of Interest: No conflict of interest was declared by the authors.

Financial Disclosure: The authors declared that this study received no financial support.

\section{References}

1. Krishnan V, Daniel ST, Lazar D, Asok A. Characterization of posed smile by using visual analog scale, smile arc, buccal corridor measures, and modified smile index. Am J Orthod Dentofacial Orthop 2008; 133: 515-23.

2. Bhuvaneswaran M. Principles of smile design. J Conserv Dent 2010; 13: 225-32.

3. Kokich VO Jr, Kiyak HA, Shapiro PA. Comparing the perception of dentists and lay people to altered dental esthetics. J Esthet Dent 1999; 11: 311-24.

4. Goldstein RE. Study of need for esthetics in dentistry. J Prosthet Dent 1969; 21: 589-98.

5. Gochman DS. The measurement and development of dentally relevant motives. J Public Health Dent 1975; 35: 160-4.
6. Peck $S$, Peck $L$, Kataja $M$. The gingival smile line. Angle Orthod. 1992; 62: 101-2.

7. Zachrisson BU. Esthetic factors involved in anterior tooth display and the smile: vertical dimension. J Clin Orthod 1998; 32: 43245.

8. Özdemir $H$, Köseoğlu $M$, Bayindir $F$. An investigation of the esthetic indicators of maxillary anterior teeth in young Turkish people. J Prosthet Dent 2018; 120: 583-8.

9. Machado AW, Moon W, Gandini LG Jr. Influence of maxillary incisor edge asymmetries on the perception of smile esthetics among orthodontists and laypersons. Am J Orthod Dentofacial Orthop 2013; 143: 658-64.

10. Özdemir H, Köseoğlu M. Relationship between different points on the face and the width of maxillary central teeth in a Turkish population. J Prosthet Dent 2019; 122: 63-8.

11. Sarver DM. The importance of incisor positioning in the esthetic smile: the smile arc. Am J Orthod Dentofacial Orthop 2001; 120: 98-111.

12. Rufenacht CR. Fundamentals of esthetics. 1th ed. Chicago: Quintessence; 1990.

13. Tjan AH, Miller GD, The JG. Some esthetic factors in a smile. J Prosthet Dent 1984; 51: 24-8.

14. Chiche G, Pinault A. Esthetics of anterior fixed prosthodontics. 1th ed. Chicago: Quintessence; 1994.

15. Kokich VO, Kokich VG, Kiyak HA. Perceptions of dental professionals and laypersons to altered dental esthetics: asymmetric and symmetric situations. Am J Orthod Dentofacial Orthop 2006; 130: 141-51.

16. Pinho S, Ciriaco C, Faber J, Lenza MA. Impact of dental asymmetries on the perception of smile esthetics. Am J Orthod Dentofacial Orthop 2007; 132: 748-53.

17. Ker AJ, Chan R, Fields HW, Beck M, Rosenstiel S. Esthetics and smile characteristics from the layperson's perspective: a computer-based survey study. J Am Dent Assoc 2008; 139: 131827.

18. Koseoglu M, Bayindir F. Effects of gingival margin asymmetries on the smile esthetic perception of dental professionals and lay people. J Esthet Restor Dent 2020; 32: 480-6.

19. Köseoğlu M, Özdemir H, Bayındır F. The evaluation of different smile parameters in the Turkish population. Int Dent Res 2018; 8: 1-6.

20. Rodrigues Cde D, Magnani R, Machado MS, Oliveira OB. The perception of smile attractiveness. Angle Orthod 2009; 79: 6349.

21. Rosenstiel SF, Rashid RG. Public preferences for anterior tooth variations: a web-based study. J Esthet Restor Dent 2002; 14: 97-6.

22. Flores-Mir C, Silva E, Barriga MI, Lagravere MO, Major PW. Lay person's perception of smile aesthetics in dental and facial views. J Orthod 2004; 31: 204-9.

23. Prasad V, Tandon P, Sharma VP, Singh GK, Maurya RP, Chugh V. Photographical evaluation of smile esthetics after extraction orthodontic treatment. Journal of Orthodontic Research 2015; 3: 49-56.

24. Correa BD, Vieira Bittencourt MA, Machado AW. Influence of maxillary canine gingival margin asymmetries on the perception 
of smile esthetics among orthodontists and laypersons. Am J Orthod Dentofacial Orthop 2014; 145: 55-63.

25. Al Taki A, Khalesi M, Shagmani M, Yahia I, Al Kaddah F. Perceptions of Altered Smile Esthetics: A Comparative Evaluation in Orthodontists, Dentists, and Laypersons. Int J Dent 2016; 2016: 7815274.

26. Eduarda Assad Duarte M, Martins Machado R, Fonseca Jardim da Motta A, Nelson Mucha J, Trindade Motta A. Morphological Simulation of Different Incisal Embrasures: Perception of Laypersons, Orthodontic Patients, General Dentists and Orthodontists. J Esthet Restor Dent 2017; 29: 68-78.

27. Álvarez-Álvarez L, Orozco-Varo A, Arroyo-Cruz G, JiménezCastellanos E. Width/Length Ratio in Maxillary Anterior Teeth. Comparative Study of Esthetic Preferences among Professionals and Laypersons. J Prosthodont 2019; 28: 416-20.

28. Geron S, Atalia W. Influence of sex on the perception of oral and smile esthetics with different gingival display and incisal plane inclination. Angle Orthod 2005; 75: 778-84.

29. Kerosuo H, Al Enezi S, Kerosuo E, Abdulkarim E. Association between normative and self-perceived orthodontic treatment need among Arab high school students. Am J Orthod Dentofacial Orthop 2004; 125: 373-8.

30. Beyer JW, Lindauer SJ. Evaluation of dental midline position. Semin Orthod 1998; 4: 146-52.

31. Sharma N, Rosenstiel SF, Fields HW, Beck FM. Smile characterization by U.S. white, U.S. Asian Indian, and Indian populations. J Prosthet Dent 2012; 107: 327-35.

32. Parekh SM, Fields HW, Beck M, Rosenstiel S. Attractiveness of variations in the smile arc and buccal corridor space as judged by orthodontists and laymen. Angle Orthod 2006; 76: 557-63.

33. Akinboboye B, Umesi D, Ajayi Y. Transcultural perception of maxillary midline diastema. Int J Esthet Dent 2015; 10: 610-7.

34. Kumar S, Gandhi S, Valiathan A. Perception of smile esthetics among Indian dental professionals and laypersons. Indian J Dent Res 2012; 23: 295.

35. Dong JK, Rashid RG, Rosenstiel SF. Smile arcs of Caucasian and Korean youth. Int J Prosthodont 2009 ;22: 290-2.

36. Hulsey CM. An esthetic evaluation of lip-teeth relationships present in the smile. Am J Orthod 1970; 57: 132-44.

37. Wolfart S, Thormann H, Freitag S, Kern M. Assessment of dental appearance following changes in incisor proportions. Eur J Oral Sci 2005; 113: 159-65.

38. Pinzan-Vercelino CRM, Costa ACS, Ferreira MC, Bramante FS, Fialho MPN, Gurgel JA. Comparison of gingival display in smile attractiveness among restorative dentists, orthodontists, prosthodontists, periodontists, and laypeople. J Prosthet Dent 2020; 123: 314-21.

39. Correa BD, Vieira Bittencourt MA, Machado AW. Influence of maxillary canine gingival margin asymmetries on the perception of smile esthetics among orthodontists and laypersons. Am J Orthod Dentofacial Orthop 2014; 145: 55-63.

40. Machado RM, Assad Duarte ME, Jardim da Motta AF, Mucha JN, Motta AT. Variations between maxillary central and lateral incisal edges and smile attractiveness. Am J Orthod Dentofacial Orthop 2016; 150: 425-35.

41. Hussain A, Louca C, Leung A, Sharma P. The influence of varying maxillary incisor shape on perceived smile aesthetics. J Dent 2016; 50: 12-20.

42. Ioi H, Kang S, Shimomura T, Kim SS, Park SB, Son WS, et al. Effects of vertical positions of anterior teeth on smile esthetics in Japanese and korean orthodontists and orthodontic patients. J Esthet Restor Dent 2013; 25: 274-82.

43. Pithon MM, Matos VO, da Silva Coqueiro R. Upper incisor exposure and aging: Perceptions of aesthetics in three age groups. J World Fed Orthod 2015; 4: 57-62.

44. Silva BP, Jiménez-Castellanos E, Martinez-de-Fuentes R, Greenberg $J R$, Chu S. Laypersons' perception of facial and dental asymmetries. Int J Periodontics Restorative Dent 2013; 33: 162-71.

45. Machado AW, McComb RW, Moon W, Gandini LG Jr. Influence of the vertical position of maxillary central incisors on the perception of smile esthetics among orthodontists and laypersons. J Esthet Restor Dent 2013; 25: 392-401.

46. Magne P, Salem P, Magne M. Influence of symmetry and balance on visual perception of a white female smile. J Prosthet Dent 2018; 120: 573-82.

47. Nelson SJ, Ash MM. Wheeler's dental anatomy, physiology and occlusion. 10th ed. St. Louis: Saunders Elsevier; 2015.

48. Sterrett JD, Oliver T, Robinson F, Fortson W, Knaak B, Russell CM. Width/length ratios of normal clinical crowns of the maxillary anterior dentition in man. J Clin Periodontol 1999; 26: 153-7.

49. Heravi F, Rashed R, Abachizadeh H. Esthetic preferences for the shape of anterior teeth in a posed smile. Am J Orthod Dentofacial Orthop 2011; 139: 806-14.

50. Witt M, Flores-Mir C. Laypeople's preferences regarding frontal dentofacial esthetics: tooth-related factors. J Am Dent Assoc 2011; 142: 635-45. 